\title{
O prawie cywilnym i karnym od Wieku Światła i Rozumu do spustoszonego stulecia
}

Keywords: Utopias, Ravaged Century, natural law

\section{Summary}

In the $18^{\text {th }}$ century the rule of ratio was supposed to rebuild the world and to make an order in it. The philosophers followed many illusions then. One of them was the belief that the ideal law is almighty and it may give happiness to the mankind. The revolution was also supposed to be a great project for the mankind. Liberty, Equality, Property (by Jan Baszkiewicz) were placed on revolutionary banners. Liberty, equality, property are the most important natural laws, which were supposed to be transformed into codes.

The $20^{\text {th }}$ century has inherited many different ideas, also utopian - coming from the Age of Enlightenment. The starting point - as usual in the utopias - was to destroy the old order, especially legal order. Two tragic totalitarian systems tried to realize these utopias. The $20^{\text {th }}$ century is called the Ravaged Century (Robert Conquest). But when the last totalitarian state in Europe fell down in the end of this century, we returned to the Enlightenment roots in penal and civil law.

Oświeceni filozofowie XVIII stulecia zajęci byli obmyślaniem projektów zmierzających do uszczęśliwienia świata, ludzkości; w swoich wyobrażeniach skutecznie przecierali ścieżki prowadzące ku szczęściu wszystkich ludzi, zaś w przerwach nie kończących się na ten temat debat sami wzruszali się i ronili łzy na myśl o przewidywanej wdzięczności przyszłych pokoleń dla ich dzieła ${ }^{1}$

1 Zob. C. L. Becker, Państwo Boże osiemnastowiecznych filozofów, tłum. J. Ruszkowski, Poznań 1995, s. 35 . 
i wpadali w zachwyt na myśl o przyszłych postępach. Schematy, systemy, plany, zarysy, prospekty, szkice, wreszcie deklaracje (mające być rodzajem katechizmów) mnożyły się jak grzyby po deszczu, bo też tworzył je każdy co ambitniejszy myśliciel epoki, która w takowych obfitowała; tworzyli je również ci, którzy nie mieli pomysłów na lepsze wykorzystanie talentów swojego pióra. Nawet tych godniejszych uwagi projektów było tak wiele, że nikt ich nie ogarniał, nie wspominając o drobniejszych, co może przypominać sympatycznie zarysowaną postać nieudacznika i gorliwca księdza de Saint-Pierre’a, który pracowicie trudził się wymyślaniem nie tylko projektów reformy żebractwa, czy utrzymywania zimowej przejezdności dróg, lecz także „projektu uczynienia z książąt i parów ludzi użytecznych dla społeczeństwa" oraz zdumiewającego samego autora, bo niebywale utopijnego, jak „projekt zaprowadzenia wiecznego pokoju w Europie"2.

Takim schematem była na przykład Kołłątajowska wizja trzech konstytucji (politycznej, ekonomicznej i moralnej) dla Polski, a w ramach konstytucji moralnej - kodeks praw sądowych. Umieszczony w artykule VIII Ustawy rządowej z 3 maja 1791 r. przepis o przewidywanym ułożeniu i wprowadzeniu w życie kodeksu prawa sądowego, który miał się nazywać Kodeksem Stanisława Augusta, stanowi przykład koncepcji uzupełniania ustawy zasadniczej. Kołłątajowska wizja dwóch dalszych konstytucji - ekonomicznej i moralnej - stanowiła koncepcję uzupełnienia konstytucji politycznej na szczeblu generalnym; dopiero z konstytucji moralnej wypływać miał kodeks prawa sądowego. Całość miała dokonać w Polsce „łagodnej rewolucji”, jak to określał ksiądz podkanclerzy, zapożyczając terminu od Gaetano Filangieriego. Ustawy moralne miały stać się "zasadą” dobrych praw cywilnych i kryminalnych, jak mówił Kołłątaj w słynnej mowie 28 czerwca 1791 r. przy powoływaniu komisji kodyfikacyjnej dla ułożenia kodeksu. W wizji Kołłątaja ustawy moralne stanowiły rodzaj religijnego, patriotycznego i obywatelskiego wychowania. Ustawy moralne miały „utworzyć charakter Polaka", natomiast kodeks prawa sądowego miał zapobiegać zepsuciu tego charakteru. Na tym polegało, iż ustawy moralne miały być „zasadą” kodeksu. $\mathrm{W}$ tej koncepcji kodeks stawał się zabezpieczeniem dla ustaw moralnych, rodzajem sankcji, strażnikiem cnoty. Warto przypomnieć, że ówcześnie prawo zaliczano do nauk moralnych, gdyż była to nauka o postępowaniu ludzi.

Stulecie XVIII - „Wiek Światła i Rozumu” - były to czasy, gdy filozofów przenikał entuzjazm przekształcania świata, zaprowadzania w nim ładu, doskonalenia go, bo też chyba po raz pierwszy w dziejach ludzkości zapanowała powszechna wiara w twórczy rozum, zdolny dokonać zmiany rzeczywistości. Podstawowym narzędziem tej mocy twórczej miało być - to oczywiste dla ówczesnych - prawo, prawo zgodne z prawami naturalnymi człowieka, wsparte na czymś w rodzaju

\footnotetext{
2 Ibidem, s. 34.
} 
kodeksu naturalnego. Nie przewidywano szczególnych trudności przy ustaleniu treści owych praw naturalnych, bo służyć miał ku temu niezawodny rozum, były one racjonalne (tak chętnie próbowano stawiać znak równania między „naturalnym” a „racjonalnym”), zaś język rozumu jest językiem samego Boga - wyjaśniał J. J. Burlamarqui, wywodząc, że "przez Prawo natury rozumie się Prawo, które Bóg narzuca wszystkim ludziom i które mogą oni odkryć i poznać, kierując się samym tylko światłem rozumu [...]"3. Bóg nie pojawiał się u wszystkich mędrców epoki, chociaż obecny był u wielu, ale już nie jako twórca średniowiecznego prawa boskiego, lecz jako twórca natury rzeczy, a więc dawne prawo boskie zastępowane było przez prawo naturalne. Montesquieu napisze w Duchu praw: „Prawo na ogół jest to rozum ludzki, ile że włada wszystkimi ludami ziemi; prawa zaś polityczne i cywilne każdego narodu winny być jedynie szczególnymi wypadkami, w których objawia się ten rozum ludzki”", co dosłownie przepisze wkrótce we francuskiej Wielkiej Encyklopedii.

Rządy rozumu miały przebudować świat i zaprowadzić w nim ład. Kiedy w lecie 1789 r. deputowani francuskiego Zgromadzenia Narodowego z zapałem układali katalog owego kodeksu naturalnego, jakim miała się stać Deklaracja praw człowieka i obywatela, na pierwszym miejscu umieścili stwierdzenie o wolności i równości: „Ludzie rodzą się i pozostają wolni i równi z punktu widzenia prawa”. Nie było ani nic dziwnego, ani nic oryginalnego, że te właśnie idee ujęli byli jako wybijające się na czoło "naturalnych, świętych i niepozbywalnych” praw człowieka. Przecież od czasów Grocjusza wolność zgodnie była akcentowana przez filozofów jako naturalne prawo człowieka, ze stanu naturalnego, sprzed umowy społecznej jeszcze się wywodzące. Szeroko pojmowana wolność była tym najbardziej pożądanym do zrealizowania prawem naturalnym, bo miała oznaczać zrzucenie pęt feudalnych, miała przynieść różnicę odczuwalną zaraz. Nie przypadek to, że Jan Jakub Rousseau zacznie swoje dzieło słowami: "Człowiek urodził się wolny, a wszędzie jest w okowach. [...] Jak się dokonała ta zmiana?” i złoży obietnicę wyjaśnienia, co mogłoby tę zmianę "uprawomocnić” (Umowa społeczna). Filozofowie dawali recepty niezawodne: to doskonałe prawo, a więc to mądry prawodawca załatwi przejście do królestwa sprawiedliwości i szczęśliwości. (W ogóle mieli wizję historii jako postępu ku doskonałości.) Tkwi w tym przekonaniu utopia nie tylko doskonałego prawa, lecz także utopia mądrego i dobrego prawodawcy. Pamiętać warto, że Morusowską wyspę szczęśliwości o najlepszym ustroju - Utopię urządził właśnie mądry prawodawca - Utopus.

Posłużenie się rozumem wydawało się więc względnie proste i skuteczne: kiedy reprezentanci francuskiego narodu przystępowali latem 1789 r. do usta-

${ }^{3}$ Cyt. za: P. Hazard, Myśl europejska w XVIII wieku. Od Monteskiusza do Lessinga, tłum. H. Suwała, Wstęp S. Pietraszko, Warszawa 1972, s. 143.

${ }_{4}$ Montesquieu, O duchu praw, tłum. T. Boy-Żeleński, przejrzał i uzup. M. Sczaniecki, Warszawa 1957, t. 1, s. 32. 
lenia Praw Człowieka i Obywatela, zadanie widziano jako proste i łatwe, bo chodziło o ujawnienie prawd ewidentnych, jasnych jak słońce ${ }^{5}$. Paradoksalne z pozoru więc były straszliwe spory i diametralne różnice zdań, jakie się na tym tle ujawniły w toku dyskusji na forum Zgromadzenia Narodowego; tylko z pozoru paradoksalne, bo tak naprawdę nic nie było jasne ani oczywiste. Naprawdę paradoksalne zaś było, że tysiącosobowe francuskie Zgromadzenie w takich warunkach po tygodniu niemal jednomyślnie uchwaliło tekst Deklaracji spójny, elegancki', który z satysfakcją czyta się po dwustu latach. Deklaracja „była zarazem aktem urodzin nowożytnego francuskiego legicentryzmu. [...] niemal każdy artykuł Deklaracji Praw, po nader oszczędnym zdefiniowaniu owych praw człowieka i obywatela, bardzo ufnie powierzał pozytywnemu ustawodawstwu określenie tego co najistotniejsze, a więc treści tych praw, ich granic, sposobów korzystania z nich, ich gwarancji wreszcie"?.

„Wcielenie wielkich wartości, zapisanych w Deklaracji Praw Człowieka i Obywatela, w system praw pozytywnych wydawało się oczywistą i łatwą metodą zapewnienia ich słuszności. Deklaracja Praw pojmowana była jako matryca całego prawodawstwa, jako imperatywna dyrektywa dla twórców konstytucji i ustaw zwykłych". To filozofowie-prawnicy, kreśląc wizję stworzenia doskonałego świata przy pomocy prawa pisanego, nakreślili wizję uszczęśliwienia ludzkości przez prawo. I chociaż bardziej byli oni filozofami aniżeli prawnikami, to jednak zauważyć warto, iż w utopijnej koncepcji doskonałego prawa prawnicy mieli okazję wystąpić w roli budowniczych doskonałego świata, w roli wizjonerów i twórców. Nadzieja złożona w ten sposób została w ręce tych, którzy mieli stworzyć doskonałe prawo, którzy mieli naszkicować wizję idealnej krainy ${ }^{8}$.

Wcześniej jeszcze twórca idei liberalizmu, John Locke, wśród najważniejszych praw naturalnych na planie pierwszym chciał widzieć prawo własności, co także było zwiastunem czasów nowych. Zwłaszcza że naturalne prawo własności miało być wolne od wszelkich feudalno-rodowych ograniczeń.

Podobnie równość wszystkich ludzi oznaczała nadejście nowych czasów, oznaczała likwidację dotychczasowego systemu prawa, prawa nierównego w swym feudalnym zróżnicowaniu stanowym. Zaś zniszczenie prawa istniejącego stanowiło warunek wstępny stworzenia prawa doskonałego. Wszak to Wolter wezwał: „Chcecie mieć prawa doskonałe, to spalcie wszystkie dotychczasowe”. To typowy dla koncepcji utopijnych warunek wstępny: zburzenie ładu istniejącego, by na jego miejsce zbudować idealny, co niechybnie i nieodwołalnie

5 J. Baszkiewicz, 1789: spory o Prawa Człowieka i Obywatela, [w:] Człowiek jako obywatel, red. M. Szyszkowska, Warszawa 1995, s. 203.

6 Ibidem.

7 J. Baszkiewicz, O powołaniu czasów Rewolucji i Napoleona do kodyfikacji, „Czasopismo Prawno-Historyczne" (dalej: CPH) 2005, z. 2, s. 11.

${ }^{8}$ Zob. T. Żyro, Boża plantacja. Historia utopii amerykańskiej, Warszawa 1994, s. 55. 
zapewnić miało ludziom szczęście do końca świata. Racjonalnej - po większej części - krytyce prawa obowiązującego towarzyszyły utopijne wyobrażenia o regułach doskonałego kodeksu, który miał być zbudowany. I o tym, że taki doskonały kodeks można zbudować. I o tym, że owe utopie są racjonalne, bo przecież tworzone przy pomocy „ratio”, ludzkiego rozumu zdolnego do poznania natury człowieczej, praw naturalnych, Praw Człowieka. Jak ładnie pisała Katarzyna Sójka-Zielińska, ,jedną z iluzji, która kierowała poczynaniami Filozofów, była wiara we wszechmoc idealnego Prawodawstwa, zdolnego zapewnić powszechne szczęście ludzkości, oraz przeświadczenie, że można je zbudować w oderwaniu od prawa dotychczasowego, kierując się jedynie zapisanymi w ludzkich sercach i umysłach uniwersalnymi regułami praw natury. [...] Panuje złudzenie, że można tworzyć tę konstrukcję ex nihilo, że wystarczy kierować się naturalnym rozsądkiem, sumieniem, poczuciem sprawiedliwości, ideą zapewnienia powszechnej szczęśliwości, rewolucyjną świadomością prawną itp." To jednak tylko złudzenie, ale - zauważmy - aktualne było zarówno za czasów Woltera, jak i Lenina.

Rewolucja była wielkim projektem uszczęśliwienia społeczeństwa, przetarcia ścieżek prowadzących ku temu szczęściu, projektem podzielenia się dobrodziejstwami wolności, równości i braterstwa. Była projektem pięknym, lecz naiwnym $^{10}$. Rewolucja miała uszczęśliwić ludzi, ale Robespierre mawiał, że rewolucji nie robi się z kodeksem $\mathrm{w}$ ręku ${ }^{11}$; świetnie to realizował. We Francji okresu terroru zapanowała idea niszczenia a nie karania czy tym bardziej poprawiania wrogów: nie było mowy o wyważaniu proporcji winy i kary - trybunały rewolucyjne uniewinniały lub posyłały na gilotynę. Kiedy w Polsce obcy najeźdźcy wespół z rodzimą reakcją obalali dzieło Sejmu Czteroleniego, we Francji powoływano nadzwyczajny trybunał dla sądzenia kontrrewolucjonistów, a w więzieniach doszło do pierwszych masakr. Nad Sekwaną uważano, że nie czas to na prawnicze subtelności, na przestrzeganie procesowych gwarancji. Dziesiątki tysięcy ludzi padło ofiarą różnych form rewolucyjnego „wymiaru sprawiedliwości”. „Głowy spadają jak dachówki” - mówił sławetny oskarżyciel Trybunału Rewolucyjnego Fouquier-Tinville (jego spadła również).

Wolność, równość, własność (J. Baszkiewicz) wypisywano na sztandarach rewolucji. Wolność, równość, własność wszakże to nie tylko idee przetwarzane w rewolucyjne hasła, to najważniejsze naturalne prawa człowieka, które dla ich zrealizowania należało przetworzyć w przepisy kodeksowe. Przetwarzano je zarówno nad Sekwaną, jak i nad pięknym modrym Dunajem. Znamienne: zarówno w porewolucyjnej Francji, jak i w absolutystycznie rządzonej wielkiej Austrii

\footnotetext{
9 K. Sójka-Zielińska, Idee kodyfikacji napoleońskich. Od utopii do realizmu, CPH 2005, z. 2, s. 28.

10 C. L. Becker, Państwo Boże osiemnastowiecznych filozofów..., s. 35.

11 J. Baszkiewicz, Wolność, równość, własność. Rewolucje burżuazyjne, Warszawa 1981, s. 22.
} 
przekształcenia prawa poszły dość dokładnie w tym samym kierunku, mimo że szły odmiennymi drogami. Dotyczy to zresztą tak prawa prywatnego, jak i karnego. To duch czasów ${ }^{12}$.

Jak celnie wskazała ostatnio Katarzyna Sójka-Zielińska (odnosząc to do napoleońskich kodyfikacji cywilnych), kodyfikacje owej doby to „rezultat zwycięstwa pragmatyzmu kodyfikatorów nad utopijnymi wizjami Filozofów Oświecenia i szlachetnymi złudzeniami doby Rewolucji”, to „tryumf realizmu nad utopią”, „proces pozbywania się rewolucyjnych złudzeń”, zrywania „z mitem zbudowania nowego porządku prawnego ex nihilo, w oderwaniu od dziedzictwa prawnego przeszłości", a także z mitem stworzenia kodeksu doskonałego ${ }^{13}$.

Niedawna dwusetna rocznica ustanowienia (i dalszego obowiązywania) kodeksu cywilnego Francuzów - kodeksu Napoleona, naukowo świętowana nie tylko w całej Europie, przyniosła wiele okazji do stwierdzenia, jak wiele idei, zasad prawa, a nawet niekiedy konstrukcji prawnych po dwustu latach nadal jest żywych ${ }^{14}$. To właśnie wszystkie kodeksy napoleońskie, z kodeksem cywilnym na czele, stanowiły znakomity przykład zerwania $z$ iluzjami epoki rewolucyjnej i połączenia nowości z tradycją; dlatego mogły się stać w XIX w. „modelem idealnym" dla rozwiązań ustawodawczych innych państw ${ }^{15}$. Wolność, równość, własność - oświeceniowa idea wolności jednostki w kodeksie cywilnym Napoleona zamieniona została w swobodę umów, ale też laickość; równość w jednakową pozycję strony w stosunku prawnym; własność (będąca gwarantem wolności człowieka) określona została jako prawo o charakterze absolutnym, zaś definiujący prawo własności słynny art. 544 k.c. Napoleona obowiązuje w niezmienionej formie do dzisiaj ${ }^{16}$ (nawiązuje do znanego prawu rzymskiemu: ius utendi, disponendi et abutendi).

Wkrótce będzie okazja świętować dwusetną rocznicę nie tylko ustanowienia, ale także obowiązywania austriackiego kodeksu cywilnego ABGB z 1811 r. i generalne sformułowania wypadnie powtórzyć również w odniesieniu do tego kodeksu. Zauważmy: jeden to kodeks porewolucyjny, drugi wyszedł z systemu absolutyzmu oświeconego, ale oba wyrażały te same idee Oświecenia. Te dwa kodeksy cywilne - napoleoński oraz austriacki miały stać się konstytucją cywilną społeczeństwa.

${ }_{12}$ A. Lityński, O prawie cywilnym od rewolucji francuskiej do rewolucji bolszewickiej uwag kilka, [w:] Rozprawy prawnicze. Ksiega pamiątkowa Profesora Maksymiliana Pazdana, red. L. Ogiegło, W. Popiołek, M. Szpunar, Zakamycze 2005, s. 1113-1126.

${ }^{13}$ K. Sójka-Zielińska, Idee kodyfikacji napoleońskich..., s. 27.

${ }^{14}$ Materiały naukowe z największej polskiej sesji 200 lat kodyfikacji napoleońskich, zorganizowanej w Krakowie w 2004 r. drukuje CPH 2005, z. 2.

${ }^{15}$ K. Sójka-Zielińska, Idee kodyfikacji napoleońskich..., s. 27.

${ }^{16}$ B. Lewaszkiewicz-Petrykowska, Współczesne prawo cywilne a «Code civil» Napoleona jako dziedzictwo wielowiekowej kultury prawnej, CPH 2005, z. 2, s. 123. 
Szczególna rola w kształtowaniu obszaru wolności oraz dla tejże wolności zagrożeń przypada prawu karnemu. Prawo karne w ogóle stanowi czuły barometr i wskaźnik charakteru ustroju państwowego i politycznego państwa; prawo karne dotkliwie wkracza w prawa, w naturalne prawa człowieka, w tym w wolność. Z natury swej prawo karne prawa człowieka ogranicza, teoretycznie właśnie dla dobra innych jednostek oraz dla dobra ogółu, dla dobra społeczeństwa, państwa, ewentualnie narodu. Wszak wymyślony w historii cały wachlarz kar stanowi takie właśnie wkroczenie w sferę praw człowieka, ich czasowe lub trwałe ograniczenie albo nawet zniweczenie, w tym odjęcie wolności fizycznej, odjęcie życia, odjęcie własności. Nie było przypadkiem, iż w pierwszych tygodniach rewolucji nad Sekwaną w masowo napływających do Zgromadzenia Narodowego skargach Francuzów i w żądaniach zmian było szczególnie dużo skarg na brutalny system prawa karnego, czego nie przytłumiły nawet utyskiwania na zawsze źle widziane podatki.

Minęły więc czasy, gdy głównym celem prawa karnego było odstraszanie przy pomocy kary, a główną metodą dochodzenia do sentencji wyroku karnego było przyznanie się do winy uzyskane legalnie stosownymi torturami. Od czasów Monteskiusza i Beccarii subiektywizm, humanitaryzm i idea resocjalizacji wysunęły się na czoło europejskich systemów karnych, przy wyraźnym rosyjskim zacofaniu nadrabianym wszakże na początku XX stulecia.

$\mathrm{U}$ progu XX w., tuż przed I wojną światową, zasada nullum crimen sine lege wraz z uzupełniającą ją zasadą nulla poena sine lege miały za sobą karierę półtorawiekową, jeśli liczyć symbolicznie od daty (1764) pierwszego wydania wiekopomnej książeczki O przestępstwach i karach markiza z Mediolanu. Wymienione zasady nie bezpodstawnie uważane były za fundament praworządności w prawie karnym, podstawę przewidywalności poczynań władzy państwowej w zakresie prawa karnego, fundament bezpieczeństwa prawnego człowieka, co mu się z natury należy. Obie zasady przeto Deklaracja praw człowieka i obywatela ogłaszała (art. 4 i 8) za „naturalne, niepozbywalne i święte prawa człowieka”, których zabezpieczenie i przestrzeganie niezbędne miało być dla „szczęścia ogólnego”. Ta humanitarna reakcja filozofów Wieku Światła i Rozumu na przedoświeceniowy stan niepewności w prawie karnym, nad dawniejsze panowanie zasady analogii wiszącej niczym miecz Damoklesa nad człowiekiem, przekształcona została w XIX-wiecznej szkole klasycznej prawa karnego w formalną definicję przestępstwa, zabezpieczającą człowieka i obywatela przed samowolą władzy, trzeciej z władz według Monteskiuszowskiego podziału.

Koniecznie przypomnieć trzeba jeszcze zasadę lex retro non agit, również w Wieku Światła i Rozumu uznaną za fundamentalną dla rządów prawa i zaliczoną - w materii prawa karnego ${ }^{17}$ - do „naturalnych, niepozbywalnych i świętych

${ }^{17}$ Były wówczas także koncepcje nadania nieretroaktywności charakteru ogólnego. W Lafayette’a projekcie deklaracji praw człowieka z 1789 r. tak to właśnie było ujęte. Jeszcze wyraźniej i dobitniej myśl 
praw człowieka” (zob. art. 8 francuskiej Deklaracji). Zakaz stanowienia „praw ex post facto" znalazł się w amerykańskiej konstytucji, sformułowany tam dwukrotnie: w odniesieniu do praw federalnych oraz do praw stanowych ${ }^{18}$. Inaczej potraktować sprawy nie można było, wszak lex retro non agit uzupełnia nullum crimen, nulla poena sine lege; zauważmy, że dwie ostatnie bez nieretroaktywności nie przedstawiałyby żadnej wartości, w istocie nie mogłyby istnieć ${ }^{19}$.

Zachłyśnięcie się liberalizmem epoki i humanitaryzmem myśli i tendencji w prawie karnym nie przetrwało jednak wieku XIX, nie ostało się wobec nowych zjawisk gospodarczych i społecznych w drugiej połowie, a bardziej jeszcze u schyłku XIX stulecia. Industrializacja i urbanizacja na niespotykaną dotychczas skalę, wielkie przemieszczenia wewnętrzne (ze wsi do miast) mas ludności, musiały przynieść zjawiska kryminogenne, skutkować znaczącym wzrostem przestępczości ${ }^{20}$. Podobnie w prawie cywilnym Sto lat więc nie upłynęło, gdy okazało się, że najwspanialsza zdobycz wcale nie jest taka wspaniała. Zarówno zwykły niepokój (u jednych), jak też poczucie humanitaryzmu i solidaryzmu społecznego (u drugich) skutkowały reakcjami zmierzającymi do modyfikacji europejskich praw cywilnych, do powściągnięcia pełnego liberalizmu w prawie cywilnym. Kierunki tzw. socjalne w prawie cywilnym nie doprowadziły wprawdzie do zmian w już istniejących ustawodawstwach, ale wpłynęły na praktyczne prawa stosowanie, w których miejsca na absolutny liberalizm często już nie zostawiano, kontrolując społeczne skutki, ewentualną nierówność ekonomiczną stron, czyli to co będzie nazywane zasadami współżycia społecznego.

W tworzonych zaś wówczas kolejnych wielkich kodyfikacjach cywilnych Europy pojawiły się rozwiązania uelastyczniające ustawę cywilną przez oddanie $\mathrm{w}$ ręce sędziego więcej decyzji. Pojawiły się: w niemieckim BGB klauzule generalne, zaś w szwajcarskim ZGB - w niektórych sytuacjach - upoważnienie sędziego, by tak postąpił, jak gdyby sam był prawodawcą ${ }^{21}$.

niedziałania ustawy wstecz wyraził na posiedzeniu konstytuanty Mirabeau w 1790 r. Zob. W. Wołodkiewicz, Lex retro non agit, [w:] Lacińskie paremie w europejskiej kulturze prawnej i orzecznictwie sądów polskich, red. W. Wołodkiewicz i J. Krzynówek, Warszawa 2001, s. 163.

${ }^{18}$ Art.1, dział 9.3 oraz dział 10.1 .

${ }^{19}$ Józef Nowacki podniósł, że jeśli pominąć pozostałą problematykę, a badać jedynie zagadnienie lex retro non agit $\mathrm{z}$ punktu widzenia pewności prawa, to „obydwie powyższe zasady (nullum crimen sine lege i nulla poena sine lege) można bez przeszkód potraktować jako przejaw ogólniejszej zasady lex retro non agit, gdyż w konsekwencji oznaczają one, że między innymi normy prawa karnego nie mogą być stosowane do czynów popełnionych przed wejściem tychże norm w życie". J. Nowacki, Pewność prawa a zasada lex retro non agit, [w:] idem: Studia $z$ teorii prawa, Zakamycze-Kraków 2003, s. 92.

${ }^{20}$ A. Lityński, Państwo prawne w Europie u progu XX wieku. Zagadnienia prawa karnego i cywilnego, [w:] Z dziejów kultury prawnej. Studia ofiarowane Profesorowi Juliuszowi Bardachowi w dziewięćdziesięciolecie urodzin, red. zespół pod przew. M. Wąsowicza, Warszawa 2004, s. 191-203.

${ }^{21}$ A. Lityński, O prawie cywilnym od rewolucji francuskiej do rewolucji bolszewickiej..., s. 1113$-1126$. 
Warto zauważyć, że szczególną okazję do miarkowania skutków prawnych sztywnych norm „starych” kodeksów stwarzało rodzące się pod koniec XIX w. prawo pracy. Wszak tu jaskrawo uwidaczniała się faktyczna nierówność w teoretycznej równości kodeksowej; tutaj zasada swobody umów dawała drastycznie wymuszone efekty. Wówczas, u swych początków, prawo pracy traktowane było jedynie jako część prawa cywilnego: umowa o pracę to część prawa zobowiązań, to po prostu umowa. Prawo pracy wyodrębniło się z prawa cywilnego w znacznym stopniu dlatego, że zasada swobody umów - fundamentalna dla prawa cywilnego - nie zapewniała właściwej ochrony stronie słabszej - pracownikom ${ }^{22}$. Prawo pracy poszło w kierunku uregulowania niezbędnych odstępstw od zasady swobodnego kształtowania wzajemnych praw i obowiązków pracodawcy i pracownika ${ }^{23}$.

Nakładały się na to rozpowszechniające się w zmienionym systemie gospodarczym i w odmiennej rzeczywistości społecznej nowe idee społeczno-polityczne: socjalistyczne i komunistyczne. Zapowiadane w Manifeście komunistycznym widmo komunizmu krążyło po Europie, a okazało się, że krążyło także nie zapowiadane widmo faszyzmu. Sygnalizowane zjawiska tworzyły podłoże, na którym wyrosły: kierunek socjalizacji prawa cywilnego, encyklika Rerum novarum o kwestii robotniczej, m.in. głosząca stanowisko Kościoła w kwestii własności, ale też w sprawie haseł socjalistycznych i komunistycznych. Na tejże glebie ekonomicznej i socjalnej wyrosła szkoła socjologiczna prawa karnego ${ }^{24}$.

Wiek XX jest spadkobiercą rozmaitych idei, myśli, także utopijnych koncepcji epoki Oświecenia; dotyczy to m.in. utopijnych koncepcji możliwości zaprowadzenia doskonałego ładu i zapewnienia wszystkim wiecznego szczęścia i to za pomocą doskonałego prawa. Punktem wyjścia - jak to zwyczajnie w utopiach - miało być zburzenie całego dotychczasowego porządku, zwłaszcza porządku prawnego, bo doskonałe prawo miało stworzyć doskonały ład i szczęście. To Wolter wołał: chcecie mieć doskonałe prawo - spalcie całe dotychczasowe, ale zrealizował tę myśl dopiero Lenin i towarzysze. Francuska rewolucja też stanowiła ulubiony historyczny wzorzec bolszewików, co dotyczy szczególnie nurtu jakobińskiego oraz rewolucyjnego terroru.

U samego progu prawdziwego XX w., w 1917 r., w Rosji zmieciono z powierzchni ziemi cały dotychczasowy system prawa. Gdyby jednak chodziło tylko o same teksty prawa imperium Romanowych, to żalu wielkiego by nie było, bo wszak - jak cały wschodni kolos - olbrzymie było zapóźnienie ro-

${ }^{22}$ Zob. K. Kolasiński, Problem rekodyfikacji i deregulacji prawa pracy, „Studia Iuridica Torunensia”, t. 1, red. E. Kustra, Toruń 2001, s. 92.

${ }^{23}$ A. Lityński, O prawie cywilnym od rewolucji francuskiej do rewolucji bolszewickiej..., s. 1113-1126 .

${ }^{24}$ A. Lityński, Państwo prawne w Europie u progu XX wieku..., s. 191-203. 
syjskiego prawa względem wielkich kodeksów cywilnych środkowej Europy. $\mathrm{Na}$ „śmietnik historii” zwycięscy bolszewicy wyrzucili jednak niemal wszystkie nowoczesne zasady prawa prywatnego: wolność, równość, własność.

W przeciwieństwie do ostrożniejszej ideologii narodowego socjalizmu filozofia marksistowska nader optymistycznie przedstawiała komunistyczną przyszłość. Miała ona być bez państwa i bez prawa. Wszak prawo, które jest wyrazem woli klasy panującej, miało stać się bezprzedmiotowe w bezklasowym społeczeństwie komunistycznym. Państwo dyktatury proletariatu miało być tworem jedynie przejściowym; w komunizmie nie miało być klas, a więc nie miałoby być państwa, a więc tym bardziej nie miałoby być prawa. Ale to nie znaczy, że miałoby nie być władzy, czyli władzy tylko opartej na sile. Oryginalną myślą Lenina było, że posiadacze władzy politycznej mogą się całkowicie obejść bez prawa, że nie jest niezbędne nadawanie ich nakazom formy prawnej ${ }^{25}$. Nihilizm prawny Lenina-prawnika wyrażał się m.in. w poglądzie, że każde państwo to w istocie dyktatura klasowa, zaś dyktatura to „nic innego, jak władza niczym nie ograniczona, nie skrępowana żadnymi prawami, absolutnie żadnymi przepisami", opierająca się bezpośrednio na przemocy ${ }^{26}$. Marksowska koncepcja państwa całkowicie wyeliminowała element prawa. Jedynym prawem uważanym przez Marksa za pozytywną siłę miało być prawo historii, a to dawało o sobie znać przez obalanie starego porządku, ,jest akuszerką każdego starego społeczeństwa brzemiennego nowym" porządkiem ${ }^{27}$. Prawo historii jest - jak zauważyła Hannah Arendt - prawem ruchu, a więc pozostaje w jaskrawej sprzeczności z wszystkimi innymi znanymi z naszej tradycji pojęciami prawa, które to prawa są elementami stabilizującymi.

Tak w teorii. W praktyce najpierw derogowano całe dotychczasowe prawo sprzed przewrotu bolszewickiego ${ }^{28}$ i nie zamierzano się spieszyć z ustawowym (dekretowym) pełnym regulowaniem, bowiem nie chciano prawa stabilizować. Prawo miało się rozwijać w oparciu o rewolucyjną świadomość ludowych sędziów. W latach wojny domowej (1917-1921) represję karną stosowano często w sposób anarchiczny, terrorystyczny względem domniemanych przeciwników politycznych. W Rosji radzieckiej i później w ZSRR - jak wspomniałem - na

${ }^{25}$ A. Walicki, Filozofia prawa rosyjskiego liberalizmu, tłum J. Stawiński, przejrzał autor, Warszawa 1995, s. 104.

${ }^{26}$ L. Kołakowski, Główne nurty marksizmu. Powstanie - rozwój - rozkład, Londyn 1988, s. 765 (cz. 1, rozdz. 18); A. Walicki, Marksizm i skok do królestwa wolności. Dzieje komunistycznej utopii, Warszawa 1996, s. 328-329; zob. też idem, Filozofia prawa rosyjskiego liberalizmu..., s. 104; cytat z dzieł Lenina od A. Walickiego, ale jest też u L. Kołakowskiego.

${ }^{27}$ K. Marks, Kapitat. Krytyka ekonomii politycznej, t. 1, ks. 1, cyt. za: H. Arendt, Polityka jako obietnica, tłum. W. Madej i M. Godyń, red. i wprowadzenie J. Kohn, posłowie P. Nowak, Wyd. Prószyński i Ska, Warszawa [2005], s. 119.

${ }^{28}$ Bliżej zob. A. Lityński, Historia prawa radzieckiego 1917-1991. Krótki kurs, „Miscellanea Historico-Iuridica" 2005, t. 3, s. 139 i n. 
wstępie zlikwidowano całe poprzednio obowiązujące prawo, w tym prawo karne, i przystąpiono do tworzenia nowego zupełnie od podstaw, nie tyle jednak z niczego (ex nihilo, jak to się modnie określa), co ze świadomości prawnej ludzi radzieckich prawo to stosujących.

W radzieckim prawie karnym realizacją „rewolucyjnej praworządności” długo zajmował się przede wszystkim Feliks Edmundowicz Dzierżyński. Feliks Edmundowicz zaś na posiedzeniu Rady Komisarzy Ludowych miał powiedzieć: „Nie myślcie, że szukam rewolucyjnej praworządności, praworządność jest nam dziś zbędna"29. Wpisywało się to w Leninowską koncepcję dyktatury proletariatu nie skrępowanej żadnymi, nawet swoimi własnymi, prawami ${ }^{30}$. Nic nie zostało z idei Oświecenia, chociaż zostało coś z wypaczonych koncepcji szkoły socjologicznej prawa karnego.

W prawie radzieckim od Lenina pochodziła teza ideologiczna, że w społeczeństwie socjalistycznym nie ma przeciwstawności między interesami jednostki i społeczeństwa, a wręcz przeciwnie - istnieje w tym zakresie jedność, a nadto że $\mathrm{w}$ ustroju tzw. socjalistycznym nieuzasadniony jest podział na prawo publiczne i prywatne. W 1922 r. Lenin tak kreślił zadania radzieckiego resortu sprawiedliwości: „[...] zadaniem jest stworzenie nowego prawa cywilnego, a nie przyswajanie sobie starej, burżuazyjnej koncepcji prawa cywilnego (czy też raczej pozwalanie, aby oszukiwali nas starzy i głupi prawnicy burżuazyjni, którzy tak właśnie postępują) [...]. Nie ma dla nas nic "prywatnego», wszystko w dziedzinie gospodarczej jest dla nas rzeczą publicznoprawną, a nie prywatną. [...] Stąd konieczność szerszej ingerencji państwa w sferę «stosunków prywatnoprawnych», rozszerzenia uprawnień państwa w zakresie uchylania umów "prywatnych», stosowania wobec «cywilnych stosunków prawnych» nie corpus iuris Romani, lecz naszej rewolucyjnej świadomości prawnej [...]"31. Nie ma rzeczy i spraw prywatnych, a w ogóle komunizm wyklucza prawo. Wszak prawo jest narzędziem wyzyskiwaczy służącym do zniewalania ludzi przez uniemożliwianie wyzyskiwanym połączenia swoich sił w celu wyzwolenia społecznego i ekonomicznego, a prawnicy zaś to najbardziej reakcyjni ludzie na świecie - uważał prawnik-Lenin. Takie były początki, ale dynamika przemian radzieckiego prawa prowadziła od „dziecięcej choroby lewicowości” Manifestu komunistycznego i samego Lenina do NEP-u i - mimo stalinizmu - do powolnego cywilizowania prawa na gruncie tradycyjnych rozwiązań.

Prawo karne i cywilne Europy wkroczyło w XX w. w zasadzie dobrze przygotowane do spełnienia roli, jaką nie tylko sto lat temu, ale także i dzisiaj - na

${ }^{29}$ Cyt. za: M. Filar, W stużbie utopii. 73 lata radzieckiego prawa karnego, Toruń 1992, s. 11.

${ }^{30}$ A. Walicki, Marksizm i skok do królestwa wolności. Dzieje komunistycznej utopii, Warszawa 1996, s. 328-329.

${ }^{31}$ Cyt. za: A. Walicki, Marksizm i skok do królestwa wolności. Dzieje komunistycznej utopii, Warszawa 1996, s. 339; zob. toż w wersji niepełnej: Lenin, Dzieła, t. 36, Warszawa 1958, s. 594. 
początku XXI w. - winno spełniać w charakterze ważnych filarów praworządności, czyli jako ważny czynnik państwa prawa. Dowody na poparcie tej tezy są proste: $\mathrm{w}$ zasadzie to wszystko, co $\mathrm{w}$ obu gałęziach prawa ludzie stworzyli w późnym Oświeceniu i przez cały wiek XIX - wszystko to nadal jest aktualne. Od około dwustu lat $\mathrm{w}$ istocie nie wymyśliliśmy ani w prawie karnym, ani w prawie cywilnym żadnych wielkich nowości; tak wielkich, że zmieniałyby w ogóle nasz sposób patrzenia na określone zjawiska prawne. Korzenie wszystkich podstawowych zjawisk prawa karnego i cywilnego prowadzą do rozwiniętego Oświecenia, z uzupełnieniami przez nauki XIX w. Nie przypadkiem w XXI w. nadal obowiązują niektóre XIX-wieczne kodeksy, w tym wszystkie najważniejsze cywilne. Obowiązują one w państwach, które dość zgodnie uważamy w XXI w. za państwa prawne.

Wiek XX to spustoszone stulecie (Robert Conquest), co dotyczy szczególnie naszej części Europy. Wielkie problemy XX w. - jak wszyscy świetnie wiemy - tkwią właśnie w tym, że pojawiły się systemy polityczno-prawne rażąco nie tylko naruszające zasady państwa prawnego, lecz wręcz te zasady niweczące. Czerwony i brunatny - totalitarne systemy wykazujące nihilizm prawny i pogardę dla człowieka, a tym bardziej dla najbardziej elementarnych praw człowieka były zagrożeniem dla całej kultury, w tym wielowiekowej kultury prawnej człowieka. Nie była to zresztą i nie jest cecha tylko Starego Kontynentu. „I tak oto utożsamianie prawa z rzekomą lub domniemaną korzyścią narodu zmieniło państwo prawa w państwo bezprawia"32 - powiedział Gustaw Radbruch w słynnym wystąpieniu Pięć minut filozofii prawa.

Kiedy jednak u schyłku spustoszonego stulecia załamało się - przynajmniej w Europie - ostatnie państwo o systemie totalitarnym, kiedy liczne narody w naszej części Starego Kontynentu znowu wybiły się na niepodległość, wróciliśmy do oświeceniowych korzeni w prawie karnym i cywilnym. W Trzeciej Rzeczypospolitej, w czwartej w XX stuleciu konstytucji (a siódmej, jeśli liczyć tzw. małe konstytucje), znalazły się jako konstytucyjne oświeceniowe zasady ochrony własności prywatnej oraz liberalizmu gospodarczego (art. 20-22), co stanowi fundament wielkich kodyfikacji cywilnych od kodeksu cywilnego Francuzów (Napoleona) poczynając. Wolność jest szczególnie częstym pojęciem pojawiającym się zwłaszcza w rozdziale II konstytucji RP z 1997 r.; chodzi zarówno o wolność poczynań gospodarczych i prywatnoprawnych, jak i wolność osobistą w sferze prawa karnego. Równość wobec prawa (art. 32 konstytucji RP) to z Oświecenia pochodząca zasada zarówno prawa cywilnego, jak i karnego (i nie tylko tych gałęzi prawa).

${ }^{32}$ G. Radbruch, Pięć minut filozofii prawa, Colloquia Communia 1988-1989, 6(41)-1(42), s. 61, cyt. za: J. Zajadło, Formuła Radbrucha. Filozofia prawa na granicy pozytywizmu prawniczego i prawa natury, Gdańsk 2001, s. 292. 
Oświeceniowe zasady nullum crimen sine lege, nulla poena sine lege, lex retro non agit znalazły się nie tylko w polskim kodeksie karnym z 1997 r., ale także w konstytucji RP (art. 42), podobnie jak prawo do niezależnego sądu, domniemanie niewinności, prawo do obrony i inne (tamże, art. 42, 45).

W konstytucji spadkobiercy radzieckiego imperium - w konstytucji Rosji z 1993 r. - podobnie znalazło się zapewnienie nienaruszalności własności prywatnej (art. 8 ust. 2, art. 35), prawo do sądu (art. 47), domniemanie niewinności (art. 49).

Konstytucja RP z 1997 r. ukształtowała się trochę jak gdyby pod wpływem oświeceniowej koncepcji konstytucji jako modelu umowy społecznej ${ }^{33}$ (konstytucja to akt tworzący nie tylko system polityczny, ale i nowe społeczeństwo), co jest zrozumiałe: po dziesiątkach lat narzuconego totalitarnego systemu odczuwano potrzebę utrwalenia możliwie wielu liberalnych i demokratycznych zasad w ustawie zasadniczej, stworzenia stosownych zabezpieczeń.

Gdy mowa o zabezpieczeniach praw człowieka, zabezpieczeniach realizacji nowoczesnych oświeconych zasad prawa, to warto zauważyć, że Europejczycy (trochę inaczej Amerykanie) dwieście lat temu nie dostrzegali potrzeby tworzenia systemu zabezpieczającego realizację praworządności. W społeczeństwie, w którym suwerenem jest naród wydawało się to niepotrzebne: skoro my, naród będziemy rządzić, realizować wolę powszechną, to któż chciałby naruszać prawo prowadzące do szczęścia nas wszystkich? Któż chciałby nakładać nam - narodowi kajdany? Sami sobie? To dopiero późniejsze, a szczególnie dwudziestowieczne doświadczenia kazały Europejczykom przesunąć punkt ciężkości na system gwarancji praw człowieka, a tym samym gwarancji realizacji wielu zasad prawa karnego i cywilnego o oświeceniowym rodowodzie (wolność, równość, nullum crimen sine lege, nulla poena sine lege, lex retro non agit i inne). W Europie XXI wieku gwarancje proceduralne wyraźnie przekroczyły granice państwowe, wkraczając na arenę międzynarodową; nie jest jednak tak, by w skomplikowanych stosunkach międzyludzkich i międzynarodowych wszystko udawało się rozumnie i praworządnie rozwiązać: czy zbrojna interwencja NATO w byłej Jugosławii (sprawa Kosowa) była działaniem praworządnym? Przeczę temu.

Tak zwana formuła Radbrucha jest również dziedzictwem II wojny światowej i sukcesem jurysprudencji połowy XX w. To małe pocieszenie wobec ogromu katastrofy w spustoszonym stuleciu, ale jednak jakieś jest. Rosja podobnej myśli się nie dopracowała. To gorzej. Najbardziej jednak dzisiaj niepokoi Ten Inny ${ }^{34}$, który zabija człowieka z pytaniem Sofoklesowej Antygony na ustach: „Czy rozkaz państwa jest ważniejszy niż nakaz Boski?"”35

\footnotetext{
${ }^{33}$ J. Baszkiewicz, Francja w Europie, Wrocław - Warszawa - Kraków 2006, s. 94.

${ }^{34}$ R. Kapuściński, Ten Inny, Kraków 2006.

${ }^{35}$ O. Pamuk, Śnieg, tłum. A. Polat, Kraków 2006, s. 55-56.
} 